\title{
How to Improve the University Legal Education
}

\author{
Xin Tang ${ }^{1, a}$ and Lishan Huang ${ }^{2, b}$ \\ ${ }^{1}$ Bauhinia apartment, Hainan University, Meilan District, No.58, Renmin Avenue, Haikou City, \\ Hainan Province, China \\ ${ }^{2}$ Bauhinia apartment, Hainan University, Meilan District, No.58, Renmin Avenue, Haikou City, \\ Hainan Province, China \\ a1370409927@qq com, ${ }^{b} 1611021604 @ q q$ com
}

Keywords: legal education, legal profession, extrajudicial education

\begin{abstract}
There are many problems in the law education of China. However, the problems ultimately point to the weak contact between the law education and legal profession. So enhancing the connection between the two is a prescription for perfecting education of the university law and even cure the education of our university law. First of all, on the education of law under the premise of clear positioning, from the perspective of the education mode, the teaching mode of "speakers" should be combined with the case teaching mode of "actors", but the priorities must be paid attention to. Secondly, the strengthening of faculty has become a focus of concern. In the process of perfecting the law education of university, teachers occupy an unshakable position. Once again, outside the law education is a bright spot. Finally, it is more and more important to open the door of the law for jurisprudence. Offering the course of western legal thought history is undoubtedly the key to open the door of law.
\end{abstract}

\section{The status of legal education}

What kind of role does the law education play in people's minds? Is it indispensable or optional?

In Western countries, the law education has a natural connection with the legal profession from the date of birth. The purpose of law education is to provide vocational skills training that is sufficient to pass the vocational qualification assessment so that the trainee has the opportunity to become a member of the legal professional club. It can be seen that in Western countries only when people participate in these directly for accreditations of legal training can they get the professional qualifications which other members of the club recognized. The indispensability of this profession also determines the absolutely necessary of the law education in this mode [1].

What about China? "It is better not to study law ", that is what Zedong Mao said when he met the Red Guards. Is such a great leader not aware of the importance of law to a country? This is not the case, under the circumstances that the legislation becomes ideological, the legal profession becomes administrative, as well as legal career and legal education are not related, "It is better not to study law" may be a reasonable allocation of education resources related to policy judgments. In fact, before the education of law serving as the nurturance education of legal professionals and the law degree serving as the prerequisite of industry admittance, its existence is the image of the "beggars" who can't straight up the waist.

\section{Explore the reasons of "can't straighten up"}

Before analyzing this reason, the position of education of university law should be expounded. When you enter the law school, you want to become a judge, a prosecutor, a lawyer or a 
jurist. But what does the law education make you become? Of course, your efforts are on the one hand while the school's education is more than important. University law education can make you what kind of person is the most direct standard of the reaction law education positioning.

University law education should try to work towards the goal that what kind of legal talent is needed by the society. University law education isn't committed to train a master of law or academic talent, but the legal professional. After all, "jurist" or "law master" is only choice and talent of a few people. Most people are going to use the law for trivia in real life and solving practical problems, rather than to study the problems whose probability of occurrence are still very little but still rack their brains.

In view of this, university law education should be to cultivate legal professionals who master legal knowledge. Therefore, combining with the present situation of law education, the problem with the law education is that there is no link between the law education and the legal profession.

\section{3 " Suit the remedy to the case"}

In fact, the prescription only has a few words, which are, either taking the law degree as one of the conditions to apply for a judicial examination or taking some university law school graduates exempt from the judicial examination. As early as 1915, the Beijing government had make stipulations as following: Judges and lawyers were a career area that required eligibility, but a three-year graduate or serving teacher of the law school, or a lawyer who has been practicing for more than three years can be exempted from examinations. Although the system has some shortcomings, but we can't deny that it has a certain inspiration to modern law education [2]. After 1949, the link between the university law education and the legal profession collapsed completely and continued to this day.

How to re-establish the "legal education and legal career links" and make the link solid and reliable?_ t that is perfect law education.

\section{(A) According to the orientation of legal education to develop a scientific model of legal education.}

The education model of law is divided into two kinds, one is the teaching mode of "the speaker", the other is the case teaching mode of "the actor"[3]. Between which, "the speaker" occupies the mainstream position, "the actor" type acts as the auxiliary. The author believes that it can yet be regarded as a kind of scientific practice that taking the "speaker" teaching mode as the focus of university law education, while taking the "actor" type of teaching model interspersed in it.

First of all, the traditional Chinese model is a teaching style which is widely and subtly accepted. Secondly, the orientation of law education fundamentally determines its educational model and the task of law education, and ultimately to cultivate legal professionals. However, due to the conditions of the restrictions, it can only be cultivated in university education to master the legal knowledge of the legal profession talents. Jin Huang, president of China University of Political Science and Law, has such a view: "the growth of the legal professionals will experience three stages that are university general education, professional education of law and continuing education of legal professional, among which, the university general education is the foundation, the university major education of law is the main body, the continuing education of legal professional is the extension of university major education." This is not all can be carried out in university education, legal career continuing education can only sum up their own unique experience by numerous practices in the future. As the saying goes, "the law of life is not logic, but experience", the accumulation of experience is a continuous process. Also it is to the last step to become a legal 
professional talent and this step is long and painful. While the first step is the knowledge of law, which is the most important and scientific way of teaching.

Besides, why come up with the mode of "the actor"? It is mainly to cultivate practical skills. This is different from the "last step" mentioned above. In fact, this is only a very shallow step, which is better to grasp and transit. So it can merely play a supporting role, not be the end of the horse, especially in the university legal education stage.

\section{(B) Strengthen the faculty}

In the university law education, the teacher plays a very important role. But the teacher goes on the theoretical teaching directly when he basically finishes the theoretical study. The teacher's academic level may be high, but many of the things in practice are different from theories. Can such a teacher satisfy us to establish "the link between university law education and legal career" more quickly? Obviously it can't.

What kind of person would be better served as the implementer of the case teaching model of "the actor"? The answer is no doubt, it's the person with practical experience and participates in practice. Teachers can be sent to the local procurator ate, courts, law firms, etc., apart from the school can hire practitioners to teach practical courses. Let the students come into contact with the original practice, rather than always see the practice of teaching across a window.

\section{(C) To strengthen external legal education}

As the older generation of jurist, Shutang Yan said, the true "legal mind" must have social knowledge, broad thought and historical perspective in addition to the most important one, which is the ability to defend. "The ability to defend" refers to the legal general knowledge plus professional education, and the latter three can be classified as "external legal education". The three will become a matching agent, making it no longer difficult for students to enter the legal profession for the first time [4].

\section{(D) To set up courses on the history of western legal thought}

Some scholars have pointed out that "the law is not only a norm, but also a life pursuit of people's life and a desire for wealth, peace and order"[5]. It is not hard to see the potential value behind the law. In the excavation of this potential value, the function of thinking in the history of western legal ideology is indispensable and even necessary. Because when training and cultivating law students of university, it exists potential values in the original enlightenment of legal thinking, the inherent development of legal literacy, the invisibility of jurisprudence and the spiritual conversion of humanistic care, which are essential for them to open the door of law. But nowadays the university law education often overlook the "key to open the door", being eager to instill legal theory concepts and so on to students. Therefore, it is necessary to set up courses in the history of Western legal thought for students who have just received legal education.

\section{Conclusion}

Law education is always an "imported thing" in China, so there are many imperfections. The author thinks that the perfection of university law education will directly promotes judicial reform, which will contribute to Chinese legal system. Of course, it's essential to keep up with the times and not be the frog in the well for the law education. In the end, we can find a path that suits China best, and we must not blindly imitate other countries. 


\section{References}

[1] Fang Yang, Longjiang Chen. Education training program for outstanding legal talents in the context of the law education [J]. Legal and social, 2016(25):240-241.

[2] Liufang Fang. Ask the law education [J]. China law, 2008, (6):14-21.

[3] Yuanyuan Jia. From "narration" to "action" -law education pattern change of the theory of knowledge [J]. Journal of academic BBS, 2017, 40 (2): 108-113.

[4] Jingshu Dong. On the importance of "extrajudicial education" in contemporary Chinese law [J]. Fudan education BBS, 2015, 15(4):47-51,68.

[5] Ronggen Yu. The law of the common law and the Qiang people's common law [J], 1999 (5): 32. 